\title{
Implementation of IT-Based Learning Media Training to Improve Teachers' Pedagogic Ability
}

\author{
Agnellia Novita Fauzia \\ Department of Educational Technology \\ Universitas Negeri Surabaya \\ Surabaya, Indonesia \\ Agnellia.18018@mhs.unesa.ac.id
}

\begin{abstract}
The advancement of information technology is one of the opportunities that can be used by teachers in implementing learning more effectively. This research aims to describe the implementation of training for making IT-based learning media to improve teachers' pedagogic ability measured by aspects of practicality and effectiveness. The subjects were teachers of SD Santo Yosef Surabaya. This research was implementation research that used quantitative approach. Data collecting method used in this research were in the form of questionnaire to asses the practicality aspect and media assessment to asses the effectiveness aspect. The results showed that the training that has been evaluated through media assessment by the trainer and questionnaire score by the participants, and both have high percentages. Based on the results showed that the implementation of training in making IT-based learning media has been effective and practical.
\end{abstract} ability

Keywords—information technology; learning media; pedagogic

\section{INTRODUCTION}

Learning activities are defined as any activities of an individual to improve his/her knowledge, skills and competences. Learning is a process in which there is an activity of interaction between teacher-students and reciprocal communication that takes place in educational situations to achieve learning goals.

In the current era of disruption or commonly referred to the industrial revolution era 4.0 the progress of information and communication technology is very fast and influential in the field of education. The application of conventional learning method based on the teacher (teacher-centered) is considered no longer appropriate. Nowadays, teachers only as a companion charge of planning and creating more learning resources thus create a conducive learning environment. Edgar Dale theorized that learners obtained more information through what they "do" than what is "heard", "read" or "observed". His research results the development of the Cone of Experience. Today, this "learning by doing" has become known as "experiential learning" or "action learning". Various innovations in learning need to be done as an effort to improve the quality of learning. Computers are often used in media presentations that bring together text,audio, and image or moving [1].
One of those innovations is using learning media. Along with the advancement of technology, the media that can be used to support the learning process is increasingly diverse. According to Guerrero [2], the use of technology can help to develop a constructivist-based learning environment, the learning environment that allows students to build their own knowledge. People can learn more deeply from words and pictures than from words alone. This can be seen through learning media [3].

Learning media is one of the solutions to help teacher who has been a source of learning for their students. Media as an educational tool that can be used to deliver the messages (learning materials), so it can stimulate the attention, interest, thought, and feeling of the students in learning activities to reach the goal of teaching [4]. Some authors contend that design for computer based learning is rooted in behaviourist theories of knowledge acquisition [5], whilst others argue that the needs of different learning styles are better served by a constructivist approach [6], most particularly in "multimedia based lessons" [7]. The range of approaches based on behaviourist and/or cognitive theories is usefully summarised. Furthermore, teachers are required to be able to master the use of media in learning as stated in the pedagogical abilities that must be possessed by a teacher. But most of teachers still have not mastered the use of computers, so teaching and learning using technology is still rarely used. Many software available can be used to develop learning media that are more interactive and attract students' learning interest. The available internet facilities are also a great opportunity to be able to enrich learning material content that can be prepared for the students.

Elementary School or SD Santo Yosef Surabaya is one of the schools that stands under the Tarakanita Foundation. This school has 18 permanent teachers that are mostly young so that their computer skills are sufficient. However, some educators or teachers also still lack of ability in the field of computers or information and communication technology, so the use of information and communication technology included in the pedagogical competency category of teachers at SD Santo Yosef Surabaya to support teaching and learning activities is still not optimal. This is evidenced by the results of observations by several master students of education management UNESA that showing the pedagogical knowledge 
and abilities possessed by SD Santo Yosef Surabaya teachers are still lacking.

The lack of teacher's pedagogical competence has an impact on the lack of maximum utilization of information and communication technology from the academic side indicated by the low productivity of teachers in developing IT-based learning materials. The method of delivering learning material is still conventional and monotonous. The low pedagogic competence of teachers at SD Santo Yosef Surabaya in delivering IT-based learning material was caused by a lack of knowledge about how to find information, and not familiar using computers optimally. Most SD Santo Yosef Surabaya teachers do not understand the material and knowledge of pedagogic competencies as well as the use of IT technology as interesting and qualified learning media.

The use and development of IT-based learning media at SD Santo Yosef Surabaya is considered very important because it can support the quality of the learning process and teacher professionalism. The teachers are directed to maximize the use of information technology. The use of information technology, especially the internet, aims to enrich the content of the material to be delivered, while the application of computerbased and multimedia-based presentations is used to make the content for learning become interesting and qualified learning media.

Based on the description above, the researcher wants to Implementation of IT-Based Learning Media Training to Improve Teachers' Pedagogic Ability.

Training is prepare the participants to take certain paths of action depicted by technology and workplace organizations, and help participants improve their performance in their activities, especially regarding understanding and skills.[8] defines training as "training is the process of teaching new or existing employees the basic skills they need to carry out their jobs".

The objectives of this study are: 1) improving knowledge and understanding of teacher pedagogic competencies; 2) improving the use of information technology and the use of the internet to support the learning process; 3) improve in productivity and creativity of teachers in learning media at SD Santo Yosef Surabaya.

\section{METHOD}

This research includes the type of implementation research. The subjects in this study were the teachers of SD Santo Yosef Surabaya. This implementation activity is carried out using the Critical Event Model [9].

TABLE I. STAGE OF ACTIVITY IMPLEMENTATION

\begin{tabular}{|l|l|l|}
\hline No. & \multicolumn{1}{|c|}{ Steps } & \multicolumn{1}{c|}{ Activities } \\
\hline 1. & $\begin{array}{l}\text { Identifying } \\
\text { Organizational Needs }\end{array}$ & $\begin{array}{l}\text { Observation, Checklist, } \\
\text { questionnaire to all teachers of SD } \\
\text { Santo Yosef }\end{array}$ \\
\hline
\end{tabular}

\begin{tabular}{|c|c|c|}
\hline 2. & $\begin{array}{l}\text { Specifying Job } \\
\text { Implementation }\end{array}$ & $\begin{array}{l}\text { Based on the results of } \\
\text { observations, checklists, and } \\
\text { questionnaires, it results that the } \\
\text { teacher competencies need to be } \\
\text { improved on pedagogic } \\
\text { competencies, especially in the } \\
\text { manufacture of learning media in } \\
\text { accordance with the character or } \\
\text { type of learning. }\end{array}$ \\
\hline 3. & $\begin{array}{l}\text { Identifying Participant } \\
\text { Needs }\end{array}$ & $\begin{array}{l}\text { Recapitulate from the checklist } \\
\text { and questionnaire that all teachers } \\
\text { have filled. From the recap, the } \\
\text { results obtained are the training } \\
\text { that will be carried out related to } \\
\text { the character or type of learning } \\
\text { participants, such as kinesthetic, } \\
\text { visual, audio, and audio visual. So } \\
\text { it must refer to the four types of } \\
\text { learning (according to the } \\
\text { questionnaire distributed to the } \\
\text { teachers) }\end{array}$ \\
\hline 4. & Determining Objectives & $\begin{array}{l}\text { There are } 2 \text { objectives of } \\
\text { implementing training in } \\
\text { accordance with the needs or } \\
\text { problems, namely general and } \\
\text { specific goals. The general } \\
\text { purpose is to understand the } \\
\text { characteristics of students and the } \\
\text { components of the subject. The } \\
\text { specific purpose is that the teacher } \\
\text { is able to create media according } \\
\text { to } 5 \text { subjects based on four types } \\
\text { of student learning (kinesthetic, } \\
\text { visual, audio, and audio visual). }\end{array}$ \\
\hline 5. & Choosing curriculum & $\begin{array}{l}\text { what is meant in choosing the } \\
\text { curriculum is what material will } \\
\text { be delivered when the } \\
\text { implementation of training and } \\
\text { materials that are appropriate to } \\
\text { the training on learning media are } \\
\text { as follows (just an idea and can be } \\
\text { added or rearranged): } \\
\text { - The concepts of learning media } \\
\text { based on the students' type of } \\
\text { learning, such as kinesthetic, } \\
\text { visual, audio, and audio visual. } \\
\text { - Characteristics of learning media } \\
\text { - Theories for kinesthetic, visual, } \\
\text { audio, and audio visual learning } \\
\text { types. } \\
\text { - How to make media } \\
\text { - Practice for creating media }\end{array}$ \\
\hline 6. & $\begin{array}{l}\text { Choosing Learning } \\
\text { Strategies }\end{array}$ & $\begin{array}{l}\text { Choosing learning strategies } \\
\text { (strategies in implementing } \\
\text { training): a blend of classical and } \\
\text { practice. In the implementation of } \\
\text { making media, the resource person } \\
\text { initially demonstrated how to } \\
\text { make the media and then the } \\
\text { training participants practiced the } \\
\text { creation of media guided by } \\
\text { resource persons or organizers. }\end{array}$ \\
\hline 7. & $\begin{array}{l}\text { Obtaining Needs } \\
\text { Identification Resources }\end{array}$ & $\begin{array}{l}\text { Learning resources: books, } \\
\text { educators, modules, etc. }\end{array}$ \\
\hline
\end{tabular}




\begin{tabular}{|c|c|c|}
\hline 8. & Conducting Training & $\begin{array}{l}\text { a. A briefing was held before the } \\
\text { training } \\
\text { b. The resource person conveyed } \\
\text { the concept of learning media, } \\
\text { the students' type of learning, } \\
\text { the characteristics of learning } \\
\text { media } \\
\text { c. Session } 1 \text { feedback } \\
\text { d. Ice breaking } \\
\text { e. Resource persons practice } \\
\text { how to make learning media } \\
\text { f. All participants make learning } \\
\text { media. }\end{array}$ \\
\hline 9. & Evaluation & $\begin{array}{l}\text { a. All participants present their } \\
\text { media and assessed by the } \\
\text { trainer. } \\
\text { b. } \begin{array}{l}\text { All participants filled the } \\
\text { questionnaire. }\end{array}\end{array}$ \\
\hline
\end{tabular}

Through training in the introduction of information technology, participants those are SD Santo Yosef Surabaya's teacher are expected to be able to add insight and knowledge about the development of information technology, specifically in the application of information technology media to support learning, so that participants can implement maximally in the learning process.

The training was conducted by delivering material related to pedagogic competencies, student learning types, and learning media by optimizing the use of computers such as Power Point, MS Word, Excel, Corel

Assignment of making media for training participants to compile learning media in accordance with their respective fields / subjects for the needs of the teaching and learning process.

Evaluation of learning media is done by presenting the media and assessed by the trainer after the training process, to see how far the training material can be received by participants / teachers.

TABLE II. EVALUATION INDICATORS

\begin{tabular}{|l|l|l|l|l|l|}
\hline \multirow{2}{*}{ No. } & \multicolumn{1}{|c|}{ Indicators / Aspects assessed } & \multicolumn{3}{c|}{ Score } \\
\hline & \multicolumn{1}{|l}{ I. } & Material Aspects & $\mathbf{2}$ & $\mathbf{3}$ & $\mathbf{4}$ \\
\hline & $\begin{array}{l}\text { Compatibility of material related with } \\
\text { curriculum fields. }\end{array}$ & & & & \\
\hline & $\begin{array}{l}\text { Clarity of material concepts delivered on } \\
\text { learning media. }\end{array}$ & & & & \\
\hline & $\begin{array}{l}\text { Suitability of animation in interactive } \\
\text { learning media with mathematical concepts } \\
\text { in matter. }\end{array}$ & & & & \\
\hline & $\begin{array}{l}\text { Animation clarity in delivering material on } \\
\text { learning media. }\end{array}$ & & & & \\
\hline & $\begin{array}{l}\text { Ease of description of material to be } \\
\text { understood. }\end{array}$ & & & & \\
\hline & $\begin{array}{l}\text { Conformity of concepts in learning media } \\
\text { with student learning types. }\end{array}$ & & & \\
\hline Media Aspects & & & & \\
\hline & Clarity of work instructions & & & & \\
\hline & Visually attracts students. & & & \\
\hline & Clarity of text displayed. & & & \\
\hline & The sentence used is easy to understand. & & & \\
\hline & The order between pages is appropriate. & & & & \\
\hline
\end{tabular}

\begin{tabular}{|c|l|l|l|l|l|}
\hline \multirow{3}{*}{ No. } & \multicolumn{1}{|c|}{ Indicators / Aspects assessed } & \multicolumn{3}{c|}{ Score } \\
\cline { 3 - 6 } & & $\mathbf{1}$ & $\mathbf{2}$ & $\mathbf{3}$ & $\mathbf{4}$ \\
\cline { 2 - 6 } & The color of each page is appropriate. & & & & \\
\cline { 2 - 6 } & The animation used is easy to understand. & & & & \\
\hline & $\begin{array}{l}\text { Animation is used in accordance with the } \\
\text { characteristics of students. }\end{array}$ & & & \\
\hline & Total & & & & \\
\hline
\end{tabular}

The data analyzed for media quality assessment on the effectiveness aspect is assessment of participants' media by the trainer. Media effectiveness analysis that seen from the classical completeness result. Completeness of training achievement achieves success, if $75 \%$ of training participants obtain the average score is 3 .

Practicality aspects assessed by questionnaire result. The questionnaire answer consists of 4 options, namely strongly agree, agree, disagree, and strongly disagree. To analyze the questionnaire data then carried out the following steps [10]

a. Calculate the response value of learners by the formula

$$
S_{i}=n_{i} \times A_{i}
$$$$
\mathrm{T}=\sum_{\mathrm{i}=1}^{4} S_{\max }
$$

Percentage Score $(\% \mathrm{~S})=\left(\frac{\sum_{i=1}^{4} S^{5}}{T}\right) \times 100 \%$

Explanation:

$\mathrm{T}=$ Maximum Total $\left[\sum(n \times \max\right.$ answer score $\left.)\right]$

$\mathrm{K}=$ score per option

$\mathrm{n}=$ The number of respondent

$\mathrm{A}=$ Answer scores

b. The next is determine the percentage criteria of each statement as follows [11].

TABLE III. CRiteria Per Statement

\begin{tabular}{|c|c|}
\hline Score Each Item & Interpretation \\
\hline $80 \% \leq \mathrm{K}<100 \%$ & Excellent \\
\hline $60 \% \leq \mathrm{K}<79 \%$ & Very Good \\
\hline $40 \% \leq \mathrm{K}<60 \%$ & Good \\
\hline $20 \% \leq \mathrm{K}<40 \%$ & Fair \\
\hline $0 \% \leq \mathrm{K}<20 \%$ & Poor \\
\hline
\end{tabular}

c. Calculate the number of very good and excellent criteria of the statement by the formula.

$$
\text { Score }=\frac{\text { Total of very good and excellent item }}{\text { Total item }} \times 100 \%
$$

The score obtained in presented to the criteria below.

TABLE IV. CRITERIA OF SCORE QUESTIONNAIRE INTERPRETATION

\begin{tabular}{|l|l|}
\hline Score Questionnaire & Interpretation \\
\hline $81 \%-100 \%$ & Very Practical \\
\hline $61 \%-79 \%$ & Practical \\
\hline $41 \%-60 \%$ & Reasonably Practical \\
\hline $21 \%-40 \%$ & Impractical \\
\hline $0 \%-20 \%$ & Very Impractical \\
\hline
\end{tabular}

Based on Table 4, the training can be said to be practical if the interpretation of the value of the questionnaire reached $\geq$ $41 \%$. 


\section{RESULTS AND DISCUSSION}

The first training is the delivery of material on pedagogical competencies, student learning types, and learning media followed by the practice of making learning media.

The second training was resumed from session 1 activities to provide assistance in making learning media 1 with Power Point, learning media 2 with Corel, then continued by stimulating the results of making learning media.

The third training is resume session 2 on PPT 1 learning media presentation and presentation of PPT 2 and Corel learning media. Furthermore, it is continued by simulating the results of making learning media.

The fourth training activities is conducting training evaluations. The training evaluation process was carried out on training that had been running for the previous three sessions. Selection of the best learning media, giving gifts to the best participants or groups.

The training activities conducted at Santo Yosef's Elementary School have been going well. This was seen from the enthusiasm of the participants who were very high. Evidenced by the presence of participants who were all present at the training. This indicates that the teachers positively welcomed the activities carried out. In accordance with the expectations of the school that expects activities that are the needs of each teachers, which is about mastering the pedagogical abilities of the teacher.

The constraints faced in the implementation are limited time because the school also has important activities, namely the final semester exam, but a solution can be found by looking for the best time so that the training activities can be carried out well and maximally.

The effectiveness score obtained from the results of the media presentation by the participants, it was found that $78.5 \%$ of participants had an average score above 3 . This shows that the training in making media is effective.

In line with the results of the effectiveness of the training, the results of the practicality of the training obtained from the questionnaires distributed to the training participants showed that the questionnaire value was $90 \%$ (Very Practical). Since the percentage score of questionnaire is $90 \%$, so the training in making media is categorized as practical.

Based on the results of the evaluations that have been conducted, the training participants have received material on pedagogical competencies, types of learning, and learning media materials. Participants can also use information or computer technology optimally in implementing more interesting learning. So, that the delivery of material in the classroom can be done more interestingly and students can be interested and more interactive in receiving the learning provided by the teacher in the class who has conducted the training.

\section{CONCLUSION}

The conclusions of the training results can be seen from the results effectiveness and practicality aspects, it shows that the training is effective and practical. Participants can also produce learning media in accordance with their respective subjects.

Suggestions from the training activities are the participants (teachers) expected to constantly strive to develop their abilities in the field of IT-based learning media, the knowledge gained from the training results is expected to be applied on all subjects continuously to attract students in the classroom.

\section{REFERENCES}

[1] Deliyannis, I. 2012. "From Interactive to Experimental Multimedia. In I. Deliyannis, Interactive Multimedia". Croatia: InTech.

[2] Fadaee, M. R., Eslami, E., \& Fahardian, M. (2008). Heuristic Strategies Training with the Use of Cooperative

[3] Mayer, R. E. (2005). "The Cambridge Handbook of Multimedia Learning". New York: Cambridge University Press, (Online), (htpps://book.google.co.id, accesed on July $3^{\text {rd }}, 2019$ ).

[4] Daryanto. 2010. "Media Pembelajaran". Yogyakarta: Gava Media.

[5] Dessler, Gary, 2008. "Human Resources Management". New Jersey: Prentice Hall, Inc.

[6] Gagne, R. M., Briggs, L., \& Wager, W. W. (1974). Principles of Instructional Design. Fort Worth. Texas: Harcourt, BraceJovanovich.

[7] Honebein, P. C. (1996). Seven Goals for the Design of Constructivist Learning Environments. In B. G. Wilson (Ed.), Constructivist Learning Environments, Case Studies in InstructionalDesign. (pp. 11-24). Englewood cliffs, New Jersey.: Educational Technology Publications, Inc.

[8] Clark, M. P., \& Wentworth, C. D. (1997). Constructivism and the Development of Multimedia Applications. Paper presented at the Proceedings of the 30th Annual Small College Computing Symposium, University of Wisconsin-Parkside.

[9] Nedler, Leonard. 1982. "Design Training Program: The Critical Event Model. Canada: Addison Wesley.

[10] Akdon, dan Riduwan (2009). Aplikasi Statistika dan Metode Penelitian untuk Administrasi dan Manajemen. Bandung: Dewa Ruci.

[11] Riduwan. 2010. Skala Pengukuran Variabel-variabel Penelitian. Bandung: Alfabeta. 